\title{
Attitude of Adolescent Religiosity in Sepertiga Malam Poetry Anthology by MA and SMK Students in Sleman Regency
}

\author{
Nur Aziz* \\ Indonesian Language and Literature Education of Graduate \\ School \\ Universitas Negeri Yogyakarta \\ Yogyakarta, Indonesia \\ nuraziz.2018@student.uny.ac.id
}

\author{
Anwar Efendi \\ Indonesian Language and Literature Education of Graduate \\ School \\ Universitas Negeri Yogyakarta \\ Yogyakarta, Indonesia \\ anwar@uny.ac.id
}

\begin{abstract}
This study was aimed to describe: 1) how the structure that built the Sepertiga Malam poetry anthology by MA and SMK students in Sleman Regency, 2) how the attitude of adolescent religiosity was found in Sepertiga Malam poetry anthology by MA and SMK students in Sleman Regency. This research used descriptive qualitative research methods. The data in this study were lines and stanzas contained in the Sepertiga Malam poetry anthology. The data resource in this study was the Sepertiga Malam poetry anthology by MA and SMK students in Sleman. The data collection was purposive sampling techniques with library technique, and refer and record techniques. Data analysis techniques used semiotic model reading techniques include heuristic and hermeneutic readings. There are six theme uses found in 66 poetries written by MA and SMK students. The themes contained in the poetry anthology were the themes of religiosity, humanity, love, nature, struggle, friendship. From the six themes that emerged, the highest frequency of occurrence was the theme of religiosity. The attitude of adolescent religiosity seen in the poetry were: (1) commitment to God's commands and prohibitions, (2) eager to study religious teachings, (3) be active in religious activities, (4) respect the religious symbols, (5) use religion approach in determining choices, (6) religious teachings used as a source of ideas development.
\end{abstract}

Keywords--adolescent religiosity, poetry anthology, Sepertiga Malam

\section{INTRODUCTION}

The condition of Indonesian education that has suffered setbacks in terms of the behavior of the academics such as the lack of respect for students of teachers and parents, fights or brawls between students, falling into students on drugs, the number of students who engage in free sex, cheating in taking exams, is an act which is far from noble values. Solihati (2017: 52) revealed things like bad attitudes above can occur because educational practices are too oriented towards mere cognitive development even though education is not only a matter of educating, but also forming good character or personality. this was also confirmed by Wuryandani et al (2016: 208), that students in schools are not enough to just develop their academic aspects, but also moral and spiritual aspects.
One important aspect that students must have is the aspect of good attitude or behavior. Attitudes are relatively settled tendencies that act in good or bad ways towards certain people or goods. Attitude is a predisposition or a tendency that is relatively stable and continues to behave or to react in a certain way to another person, object or institution or a particular problem (Chaplin, 1995: 43).

The attitude is certainly obtained from the results of learning or the influence of the environment. According to Bohner, Gerd, \& Wanke (2002: 5) attitudes can include affective, behavioral, and cognitive responses. For example, an enveironmentalist strongly believes that air pollution destroys the ozone layer, which increases the risk of cancer (cognitive); he may be angry or sad about the extinction of an endangered species (affective); and he uses public transportation rather than cars and participates in recycling (behavior). Thus, attitude is interpreted as a tendency to act in response to something either a response in the form of positive actions or negative actions.

In determining action, religion is believed to be the most complete set of teachings in guiding human beings to relate well to all that exists in the universe. Alim (2011: 10) explained that religion is a set of teachings which is a set of life values that must be used as a barometer for adherents in determining the choice of actions in their lives. This was confirmed by Yandel (1999: 16) that religion performs social functions that are applied in religious teachings. In other words, religion includes the totality of human behavior in daily life based on faith (belief) in God, so that all of his behavior is based on faith and obedience in carrying out one's religious teachings or religious attitudes.

There are several things that can be used as indicators of one's religious attitude, namely: (1) commitment to God's commands and prohibitions, (2) eager to study religious teachings, (3) be active in religious activities, (4) respect for religious symbols, (5) close with the scriptures, (6) using a religious approach in determining choices, (7) religious teachings used as a source of ideas development (Alim, 2011: 12).

This attitude of religiosity will be very influential if many people practice it, especially young people who are classified 
as adolescents. Adolescence is a transition period in the span of human life. Psychologically, adolescence is the age at which individuals integrate with adult society, the age at which children no longer feel below the level of older people but are at the same level, at least in terms of integration in society (adults) have affective aspects, more or less related to puberty, including striking intellectual transformation. Intellectual transformation that is typical of this way of thinking adolescents allows to achieve integration in adult social relationships, which in fact is a common characteristic of this period of development at this time (Hurlock, 2003: 206)

The development of religion in youth tends to focus on the characteristics of children or adolescents and perhaps their parents. Often the development of religion in youth reflects the standard practice of discipline practiced by adolescents (Regnerus, Smith, C., \& Smith, B., 2004: 27-38). Research conducted by Simons et al (Simons, L., Simons, R., \& Conger, 2004: 547) tests the hypothesis that adolescent religiosity is lower risk of misbehavior than adolescents who are not religious because they tend to commit to traditional values and are affiliated with conventional peers.

For some people, literary works is valued as artistic creations that contain noble values, moral values, which are useful for educating humans. These values should be adhered to by students in every activity in their lives. Literary works have several types, one of which is poetry, poetry is a concrete and artistic expression of the human mind in emotional and rhythmic language. As said by Sayuti, 2000: 65 ) writing poetry is essentially a process of giving a form of experience through the language of choice.

Literary work is a meaningful structure, with language as the medium. The language which is the media for literary works is realized in written form by the author. The function of literary work is to communicate ideas, thoughts and aesthetic feelings of the authors. Literary work in the form of poetry is a form of expression that utilizes the medium of language and depends on three things, namely the basis of expression in the form of soul experience, expression techniques and expression accuracy (Sayuti, 2000: 8)

Literary works are able to convey many things that exist in the mind of a poet so indirectly literary works such as poetry can be used as a means of education, but not cognitive education. Education in question is as stated by Solihati (2017: 52) education in the form of meanings, characteristics or anything that makes humans hard, but education that constructs life so that it is full of empirical knowledge. This is also confirmed by Nurgiyantoro (2004: 207) that literary works talk about life so as to provide a better understanding of life in the form of exploration of various forms of life. That way, literature as a means of education, is able to convey the values, messages, ideals, and feelings contained in his mind.

Poetry is a form of expression that utilizes the medium of language and depends on basic things. One of the basic things is the expression in the form of soul experience. In this poetry anthology, the themes produced by both MA and SMK students contain a lot of religious values, which means that in writing process students have religious experience so students have an attitude of religiosity in themselves. So, research on adolescent attitudes in this poetry is considered important in order to find out about adolescent religiosity attitudes found in literary works especially poetry. Therefore, this study chooses the Sepertiga Malam poetry anthology as a research object. The research is focused on the attitude of adolescent religiosity contained in the Sepertiga Malam poetry anthology by MA and SMK students in Sleman.

The anthology of the poetry entitled Sepertiga Malam studied is the work of students of Madrasah Aliyah (MA) and Vocational High Schools (SMK) which are classified as adolescents. In addition to the students getting literary subjects at school, the MA and Vocational students whose work they studied had participated in poetry writing training activities organized by Language Centers of DIY (Balai Bahasa DIY). Students receive guidance from practitioners, academics, and technical staff at Balai Bahasa DIY for ten meetings. MA and SMK students who have received this training created 66 works of poetry consisting of 31 poetry works of 9 MA students and 35 works of poetry by 10 vocational students. Each of these students certainly has a variety of background experiences, so aspects that appear in the resulting poetry will certainly be different.

This research is focusing in the study of poetry in Sepertiga Malam poetry anthology by MA and SMK students in Sleman Regency to reveal the attitude of adolescents religiosity contained in the poetry anthology.

\section{RESEARCH METHODS}

This research used descriptive qualitative research methods. Data resources in this study was in the form of words, phrases, lines, and stanzas that contained the attitude of adolescent religiosity in Sepertiga Malam poetry anthology. The data resources in this study was taken from the Sepertiga Malam poetry anthology book as many as 66 poetry by students consisting of 9 MA students as many as 31 poetries and 10 SMK students as many as 35 poetries.

The instrument used in this study was the researcher himself, the researcher as the research actor. Researchers played a role in planning, implementing, collecting data, analyzing, interpreting data, and reporting research results. The focus of this research was the attitude of adolescent religiosity contained in the Sepertiga Malam poetry anthology by MA and SMK students in Sleman Regency. The data collection technique used purposive sempling technique with library technique, and refer and record techniques. Data analysis techniques used semiotic model reading techniques include heuristic and hermeneutic readings.

\section{RESULT AND DISCUSSION}

In this study, researchers began by searching for poetry that contained the theme of religiosity. The use of themes 
contained in Sepertiga Malam poetry anthology by MA and SMK students was quite varied. There are several themes that are found in poetry anthology. Based on the results of this study, it could be seen that there were six themes that were used from 66 poetries by MA and SMK students. The themes were religiosity, humanity, love, nature, struggle, friendship. From the six themes that emerged, the highest frequency of occurrence was the theme of religiosity.

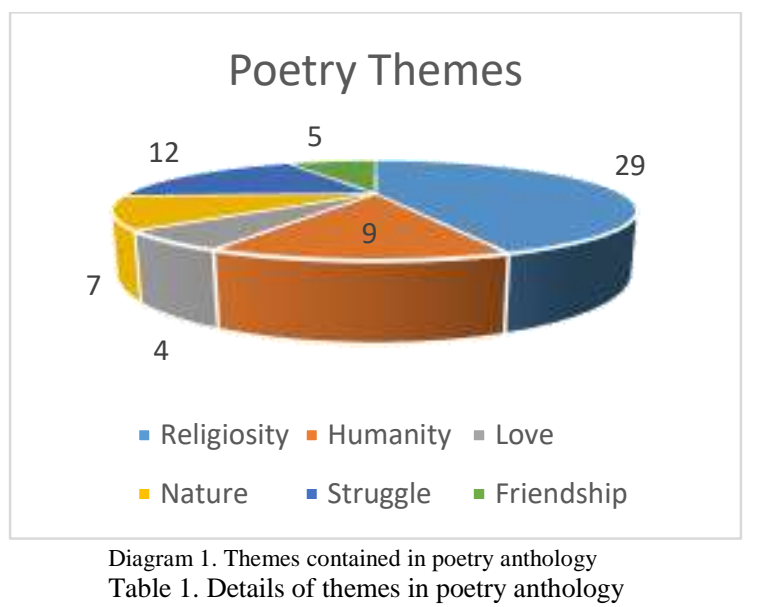

\begin{tabular}{|l|l|}
\hline Poetry Themes & Poetry Codes \\
\hline Religiosity & A1, A2, A4, K1, K5, A6, A7, A8, A9, K6, K7, \\
& K11, K12, A14, A15, A16, A18, A19, A20, K15, \\
& A21, K23, A25, A26, A29, K33, A30, A31, K35 \\
\hline Humanity & K1, A5, K13, K14, A22, K20, K21, K29, K32, \\
\hline Love & A23, K17, K22, K30, \\
\hline Nature & K3, A10, K10, K25, K26, K27, K28, \\
\hline Struggle & K4, A11, K8, K9, A12, A13, A17, K16, K18, K24, \\
& A24, K34 \\
\hline Friendship & A3, K19,A27, A28, K31, \\
\hline
\end{tabular}

From the diagrams and tables above, it could be seen that the theme of religiosity was more dominant than other themes. The theme of religiosity was in 29 poetries, the theme of humanity was in 9 poetries, the theme of love was in 4 poetries, the theme of nature was in 7 poetries, the theme of struggle was in 12 poetries, and the theme of friendship was in 5 poetries.

An example of the theme of religiosity could be seen in the following fragment of poetry.

\section{Berdua dalam Kesunyian}

Kuambil Air tuk merontokkan dosa/ Membuat jiwaku melayang dalam kesunyian/Dengan kedamaian hati, aku meminta/ Berikan rahmat dan hidayahmu/ Hidupkan kembali hati tuk terpaut selalu dengan-Mu/Sadarkan jiwa yang terbelenggu di dalam semu

\section{Together in Silence}

I take the water shedding the sin/make my soul float in silence/ with peace of heart, I ask/ give your marcy and guidance/ revive the heart to always adrift with you/awake soul that is shackled in all illusion

In the example of the poetry above, the theme of religiosity was very strong seen from every line of poetry. Nurrokhim portrayed remorse, a request to be forgiven, and asks that he always be attached to his God.

The attitude of adolescents religiosity that arised in the poetry anthology of the Sepertiga Malam is quite varied.Alim (2011: 12) explained that there were several things that could be used as indicators of one's religious attitude, namely: (1) commitment to God's commands and prohibitions, (2) eager to study religious teachings, (3) be active in religious activities, (4) respect religious symbols, (5) close with the scriptures, (6) use religious approaches in determining choices, (7) religious teachings were used as a source of ideas development.

There are six types of religious attitudes contained in the Sepertiga Malam poetry anthology by MA and SMK students.

TABLE 2: DETAILS OF ADOLESCENT RELIGIOSITY

\begin{tabular}{|c|c|c|}
\hline No & $\begin{array}{l}\text { Attitude of } \\
\text { Adolescent } \\
\text { Religiosity }\end{array}$ & Poetry codes and stanzas \\
\hline 1 & $\begin{array}{l}\text { Commitment to } \\
\text { God's commands } \\
\text { and prohibitions }\end{array}$ & $\begin{array}{l}\text { A2 Bt2, A } 4 \text { Bt1\&2, K } 2 \text { Bt1, A6 Bt2, } \\
\text { A14 Bt1, A15 Bt1, A18 Bt3, A20 Bt4 }\end{array}$ \\
\hline 2 & $\begin{array}{l}\text { Eager to study } \\
\text { religious teachings }\end{array}$ & $\begin{array}{l}\text { A1 Bt2, A16 Bt2, A21 Bt3, K23 Bt2, } \\
\text { A25 Bt1, A26 Bs 8\&9, A29 Bt1 \& Bt2 }\end{array}$ \\
\hline 3 & $\begin{array}{l}\mathrm{Be} \text { active in } \\
\text { religious activities }\end{array}$ & $\mathrm{A} 7 \mathrm{Bt} 2, \mathrm{~A} 26 \mathrm{Bs} 3 \& 4$ \\
\hline 4 & $\begin{array}{l}\text { Respect religious } \\
\text { symbols. }\end{array}$ & $\mathrm{A} 8 \mathrm{Bt} 1$ \\
\hline 5 & $\begin{array}{l}\text { Use religious } \\
\text { approaches in } \\
\text { determining } \\
\text { choices }\end{array}$ & $\begin{array}{l}\text { K2 Bt2, K5 Bt2\&3, A6 Bt3, A9 Bt2, A19 } \\
\text { Bt4, K15 Bt1 }\end{array}$ \\
\hline 6 & $\begin{array}{l}\text { Religious } \\
\text { teachings were } \\
\text { used as a source of } \\
\text { ideas } \\
\text { development. }\end{array}$ & $\begin{array}{l}\text { K6 Bt1, K7 Bt4, K11 Bt1, K12 Bt3, K15 } \\
\text { Bt1 Bs 18, K33 Bt d1, A30 Bt1, A31 Bt3, } \\
\text { K35 Bt1 }\end{array}$ \\
\hline
\end{tabular}

From the table above, it could be seen that the attitude of adolescent religiosity contained in Sepertiga Malam poetry anthology by MA and SMK students consisted of six attitudes. Commitment attitude to God's commands and prohibitions as much as eight data, attitude of eager to study religion there were seven data, be active attitude in religious activities as much as two data, attitude of respecting religious symbols of one data, attitude of using religious approach in 
determining the choices of six data, attitude of teaching religion was used as a source for developing nine ideas.

A. Commitment to God's commands and prohibitions In Sepertiga Malam poetry anthology there was a content that contained a commitment to God's command and prohibition. An example of such a load of poetry was in the following collection of poetries entitled Berdua dalam Kesunyian (MA 2).

Ampunilah hambamu ini, ya Tuhan/ Hamba takut/ takut akan siksamu/ dengan keikhlasan hatil Ku bersujud di hadapan-Mu/memikirkan alam semesta ciptaanmu

Forgive me, your servant, $O$ Lord / I am afraid / afraid of your torment / with sincerity of heart / I kneel before You / think of your created universe

The sentence that showed commitment to the command was shown in the fragment of the poetry that read ampunilah hambamu ini. In the fragment of the poetry in the Holy Qur'an the commandment was that humans were asked to always ask for forgiveness from God and forbidden to feel that they were clean from sin. In the fragment of poetry that read memikirkan alam semsta ciptaanmu contained an element of commitment to God's command. Humans were asked to think of the signs of God's greatness in the creation of heaven and earth. As explained in Al Quran Surah Al-Imran verse 190.

\section{B. Eager to study religious teachings}

Sepertiga Malam poetry anthology was expressed in a sense of excitement in terms of studying the science of religion. The spirit was shown in the fragment of the poetry entitled Gontor, Masihkah Engkau seperti Dahulu. Fragments of the poetry as follows.

Gontor.../masihkah engkau seperti dahulu?/ lantunan merdu santri membacakan kalam Illahi serta mensyiarkan syair Abu Nawas, masihkah itu?/ atau tergantikan oleh orang yang berpenampilan lusuh? (Bait 3)

Gontor ... / are you still like before? / melodious chanting of students reading the Divine Word and broadcasting the poetry of Abu Nawas, is that still? / Or replaced by someone who looks shabby? (Verse 3)

Gontor was a boarding school to demand or study religious teachings. The word "Gontor" in this peotry was repeated 4 times in the first line of each verse. Poets showed a sense of enthusiasm in remembrance when studying religious teachings in the Gontor boarding school. In the last stanza the poet mentions that Gontor would always be in the heart of the poet.
C. Be active in religious activities

In Sepertiga Malam poetry anthology by MA and SMK students, there was an emphasis on activism in religious activities such as worship. The activation was reflected in the poetry entitled Kembali ke JalanMu.

Untuk semata memenuhi panggilanNya/ Langkahlangkah ini mulai diayunkan/ tak ada jalan pulang kecuali menemuiNya/mempersembahkan hidup dan mati/ dengan segenap peribadahan/ sebagai pernyataan cinta suci yang murni. (Bait 1)

To merely fulfill His call / These steps begin to be swung / there is no turning home except to meet Him / offer life and death / with all worship / as a statement of pure holy love. (Verse 1)

Line by line in the first verse above showed that the poet was in active worship, an act of religious order. Segenap peribadahan meant various religious observances such as prayer, fasting, remembrance, charity, etc. that the poet understood and did as a form of love for his God.

D. Respect religious symbols.

Symbols in the Islamic religion such as dress shirts, chess, t-shirts, or star-shaped icons were frequently found. Examples of forms of religious symbols appeared in the following poetry entitled Jubah Hitam.

Wahai jubah hitam.../ Meskipun kini engkau tak semewah saat pertama aku meminangmu/ namun engkau tetap yang terindah milikku/ kelembutanmu selalu menemaniku saat menghadap Sang Rabb.

O black robe ... / Although now you are not as luxurious as when I first proposed to you / but you are still the most beautiful of mine / your tenderness always accompanies me when facing the Rabb.

The phrase jubah hitam symbolized an identical garment worn for worship. The poet used jubah hitam to face the Rabb. The poet greatly appreciated his jubah hitam by wearing it and even said that the jubah hitam was the most beautiful wear he ever had.

E. Use religious approaches in determining choices

The religious approach in determining choices was seen in the poetry entitled Hati yang Masih Buta

Banyak orang beralun memuji/ bagaikan diselimuti duri/ berdoa hanya kepada-Nya/ memohon agar sembuh butanya. 


\section{Many people flocked to accept / like being covered in thorns / praying only for Him / begging to recover their blindness.}

In the poetry fragment above, it appeared that the poet used a religious approach in making choices related to health. Healing from blindness was done by asking God.

F. Religious teachings were used as a source of ideas development

In Sepertiga Malam poetry anthology, in poetry entitled Matahari there was a meaning of religious teachings which were used as a source of idea development. Consider the following piece of poetry.

\section{Kebesaran menghiasi bumi/ Banyak nikmat Allah yang patut disyukuri/ Hingga hari dijalani dengan penuh ceria/ Dengan beribu raut muka \\ Greatness adorns the earth / Many favors of Allah that should be grateful / Until the day lived cheerfully / With a thousand faces}

In the fragment of the poetry above, the sentence Banyak nikmat Allah yang patut disyukuri was the teachings in the Islamic religion that was ordering people to be grateful. In the next sentence or line, the poet expressed a new idea of the benefits of being grateful, namely by being grateful that life will be lived cheerfully.

\section{CONCLUSION}

Based on the results of research and discussion on the structure that built poetry and the attitude of adolescent religiosity in Sepertiga Malam poetry anthology by MA and SMK students in Sleman Regency, some conclusions could be drawn as follows. First, the themes contained in the poetry anthology were themes of religiosity, humanity, love, nature, struggle, and friendship. Second, the attitude of adolescent religiosity contained in Sepertiga Malam poetry anthology amounted to 33 data, starting from the highest frequency, namely: (1) religious teachings were used as a source of idea development, then (2) commitment to God's commands and prohibitions, (3) eager to study religious teachings, (4) use religious approaches in determining choices, (5) be active in religious activities, (6) respect religious symbols.

\section{ACKNOWLEDGMENTS}

Thank you to Allah SWT who made it easier for the researcher in every process of the study.

Thank you to Dr. Kastam Syamsi, M. Ed. as the head of the Indonesian Language and Literature Education study program, Postgraduate Program of Yogyakarta State University
Thank you to the ICLLAE 2019 editorial team (International conference on interdisciplinary language, Literature and Education). Hopefully this journal article can be useful.

\section{REFERENCES}

Alim, Muhammad. (2011) Pendidikan Agama Islam. Bandung: PT Remaja Rosdakarya.

Bohner, Gerd \& Wanke, Michaela. (2002) Attitude and Atittude Change. New York: Psychology Press

Chaplin, JP. (1995) Kamus Lengkap Psikologi. Jakarta: PT Raja Grafindo Persada.

Hurlock, B Elizabeth. (2003) Psikologi Perkembangan. Jakarta: Erlangga

Nurgiyantoro, Burhan. 2004. "Kontribusi Sastra Anak dalam Pembentukan Kepribadian Anak”. Cakrawala Pendidikan, XXIII (2), 207

Pradopo, Rachmat Djoko. (2014) Pengkajian Puisi. Yogyakarta: Gadjah Mada University Press.

Regnerus, M. D., Smith, C., \& Smith, B. (2004). Social context in the development of adolescent religiosity. Applied Developmental Science, 8(1), 27-38. DOI: 10.1207/S1532480XADS0801_4

Sayuti, Suminto A. (2008) Berkenalan dengan Puisi. Yogyakarta: Gama Media.

Sayuti, Suminto A. (2000) Semerbak Sajak. Yogyakarta: Gama Media.

Simons, L. G., Simons, R. L., \& Conger, R. D. (2004). Identifying the mechanisms whereby family religiosity influences the probability of adolescent antisocial behavior. Journal of Comparative Family Studies, 547-563.

Solihati, Nani. 2017. "Aspek Pendidikan Karakter dalam Puisi Hamka". Litera. 16 (1), 51-63

Waluyo, Herman J. (2002) Apresiasi Puisi. Jakarta: PT Gramedia Pustaka Utama.

Wuryandari, Wuri. 2016. "Implementasi Pendidikan Karakter Kemandirian di Muhammadiyah Boarding School." Cakrawala Pendidikan, XXXV (3), hlm. 208-216.

Yandell. F. Keith. (1999) Philosophy of Religion. New York: Reutlegde 